\title{
Heterobeltiosis and Economic Heterosis for Grain Yield Related Traits of Boro Rice (Oryza sativa L.)
}

\author{
Shuma Rani Ray ${ }^{1}$, A.K.M. Aminul Islam ${ }^{1 * \mathbb{D}}$, M.G. Rasul ${ }^{1} \mathbb{D}$, M.M. Hasan Saikat ${ }^{1} \mathbb{D}$,
}

\author{
J.U. Ahmed ${ }^{2}$
}

${ }^{1}$ Department of Genetics and Plant Breeding, Faculty of Agriculture, Bangabandhu Sheikh Mujibur Rahman Agricultural University, Gazipur 1706, Bangladesh

${ }^{2}$ Department of Crop Botany, Faculty of Agriculture, Bangabandhu Sheikh Mujibur Rahman Agricultural University, Gazipur 1706, Bangladesh

\section{Article Information \\ Received: 04 January 2021 \\ Revised version received: 05 March 2021 \\ Accepted: 10 March 2021 \\ Published: 30 March 2021 \\ Cite this article as: \\ S.R. Ray et al. (2021) Int. J. Appl. Sci. Biotechnol. Vol 9(1): 45-53. DOI: 10.3126/ijasbt.v9i1.34038 \\ *Corresponding author \\ A.K.M. Aminul Islam, \\ Department of Genetics and Plant Breeding, Faculty of Agriculture, Bangabandhu Sheikh Mujibur Rahman Agricultural University, Gazipur 1706, Bangladesh \\ Email: aminulgpb@bsmrau.edu.bd}

Peer reviewed under authority of IJASBT

(C) 2021 International Journal of Applied Sciences and Biotechnology

\section{OPEN OACCESS}

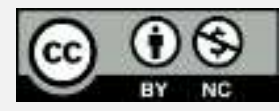

This is an open access article $\&$ it is licensed under a Creative Commons Attribution Non-Commercial 4.0 International (https://creativecommons.org/licenses/by-nc/4.0/)

Keywords: Rice; hybrid; check variety; standard heterosis; grain yield.

\begin{abstract}
Rice is a staple food for more than half of the world's population and to increase the yield potential of rice would be a key factor for mitigating global demands of about 810 million tons of rice by 2025 . To exploit the economic importance of heterosis, quantitative valuation was carried out in a randomized complete block design with three replications for 16 agronomic traits of $5 \times 5$ half diallel populations during boro season of 2017-2018. Diallel populations were generated by using five selected parents ( $\mathrm{P}_{1}$ : BRRI dhan28, $\mathrm{P}_{2}$ : BRRI dhan74, $\mathrm{P}_{3}$ : BINA dhan10, $\mathrm{P}_{4}$ : IR59418-7B-21-3 and $\mathrm{P}_{5}$ : BRRI dhan67) where, $\mathrm{P}_{1}$ was considered as standard check to estimate the economic heterosis. Analysis of variance revealed highly significant variability among the genotypes for most of the traits except grain length and length-breadth ratio. The results showed that none of the hybrid combination performed better for all the traits over the three types of heterosis. The highest relative heterosis was recorded in $\mathrm{P}_{3} \times \mathrm{P}_{4}$ followed by $\mathrm{P}_{4} \times \mathrm{P}_{5}$ for grain yield plant ${ }^{-1}$, filled grains panicle ${ }^{-1}$, effective tillers plant ${ }^{-1}$. Majority of the cross combinations $(>60 \%)$ revealed highly significant positive heterosis for grain yield plant ${ }^{-1}$ over mid parent. Heterobeltiosis for grain yield plant ${ }^{-1}$ was observed significant for $50 \%$ cross combinations and could be utilized in hybrid breeding. Whereas, more than $70 \%$ crosses exhibited undesirable negative standard heterosis for grain yield plant ${ }^{-1}$. Only two cross combinations $\left(\mathrm{P}_{3} \times \mathrm{P}_{5}\right.$ and $\left.\mathrm{P}_{3} \times \mathrm{P}_{4}\right)$ among ten revealed significant positive economic heterosis for grain yield plant ${ }^{-1}$ and those could be exploited in rice breeding.
\end{abstract}

\section{Introduction}

Rice (Oryza sativa L.) is the most important food crop in the world. Rice occupies a fundamental place since it forms the staple food for about two thirds of the world's population, provides approximately $43 \%$ calories necessity in addition to 20-25\% agriculture income (Kumar et al., 2018). Rice cultivation occupies over an area of about
167.13 million hectares worldwide with a yearly rice production of about 782.00 million tons (Kumar et al., 2020). Rice breeders are continuously trying to alter new genotypes with improved yield potential and to release them as stable high yielding varieties over the existing ones (Sundaram et al., 2019). The breeding methodology like 
ploidy along with mutation breeding has ended due to poor results. Therefore, the breeders in all the rice growing countries in the world are habitually attempting to refine the pedigree and hybrid breeding method through the utilization of biometrical as well as genetical analyses. Previously, rice genetics have been found to useful to refine the breeding methodology in the rice improvement with these prospects, an exploration was then undertaken to estimate parents and desirable crosses which would give better off-springs for superior productivity with higher breeding value. Heterosis breeding is one of the utmost important genetic tools that able to facilitate yield augmentation from $30 \%$ to $400 \%$, moreover, helps to enrich various desirable quantitative as well as qualitative characters in crops (Rahimi et al., 2010).

Heterosis or hybrid vigor refers to the phenomenon of superior performance of a hybrid over its parent in terms of biomass production, development rate, grain yield, and stress tolerance. Utilization of heterosis has tremendously increased productivity of many crops, globally. The term heterosis was first coined by Shull (1914), denotes superiority of $F_{1}$ hybrids over both of its parents in terms of yield or any other character. Jones (1926), first reported heterosis in rice and observed a tremendous increase in culm number and grain yield in $\mathrm{F}_{1}$ hybrids compared to their parents. Heterosis is usually expressed into three ways, depending on the criterion used to evaluate the performance of a hybrid (Gupta, 2000). These are mid-parent heterosis, better parent heterosis or called heterobeltiosis and standard heterosis. Heterosis breeding is a vital genetic tool that could assist in yield improvement from $30 \%$ to $400 \%$ as well as helps to augment many other desirable quantitative and qualitative traits in crops (Ghidan et al., 2019; Gupta et $a l ., 2020)$. Both the positive as well as negative heterosis is useful in crop improvement program, usually depends on breeding objectives. Generally, positive heterosis is desirable for yield while negative heterosis in concern to early maturity followed by early flowering. Exploitation of heterosis is of utmost importance for increasing agricultural productivity and also one of the most successful examples in many crops including rice (Lv et al., 2020; Ismaeel et al., 2019; Singh et al., 2019). Therefore, the objective of this study is to estimate three types of heterosis for yield related traits of boro rice.

\section{Materials and Methods}

\section{Parental Materials}

The experiment was comprised with five boro rice varieties which were collected from two research institutions viz. Bangladesh Rice Research Institute, Gazipur (BRRI) and Bangladesh Institute of Nuclear Agriculture, Mymensingh (BINA). The selected varieties were BRRI dhan28 ( $\left.\mathrm{P}_{1}\right)$, BRRI dhan74 $\left(\mathrm{P}_{2}\right)$, BINA dhan10 ( $\left.\mathrm{P}_{3}\right)$, IR59418-7B-21-3 $\left(\mathrm{P}_{4}\right)$ and BRRI dhan67 $\left(\mathrm{P}_{5}\right)$.

\section{Development of Hybrids}

The experimental hybrids were developed by using $5 \times 5$ half diallel mating design. Total of 10 direct hybrids viz. $\mathrm{P}_{1} \times \mathrm{P}_{2}$, $\mathrm{P}_{1} \times \mathrm{P}_{3}, \mathrm{P}_{1} \times \mathrm{P}_{4}, \mathrm{P}_{1} \times \mathrm{P}_{5}, \mathrm{P}_{2} \times \mathrm{P}_{3}, \mathrm{P}_{2} \times \mathrm{P}_{4}, \mathrm{P}_{2} \times \mathrm{P}_{5}, \mathrm{P}_{3} \times \mathrm{P}_{4}, \mathrm{P}_{3} \times \mathrm{P}_{5}$ and $\mathrm{P}_{4} \times \mathrm{P}_{5}$ were obtained through diallel mating among five selected parental genotypes in the boro season of 2017 . Seeds of $10 \mathrm{~F}_{1}$ 's along with their five parents were harvested and stored in the cold room of Department of Genetics and Plant Breeding, Bangabandhu Sheikh Mujibur Rahman Agricultural University (BSMRAU) for cultivating to the next boro season.

\section{Evaluation of Experimental Materials}

The $F_{1}$ populations along with their five parents were grown in the experimental field following randomized complete block design (RCBD) with three replications during boro season of 2018 following inputs and operations recommended by BRRI (2018). Data were collected from ten randomly selected plants for each replication for selected agronomic traits under study. The traits were days to panicle exertion (DPE), days to maturity (DMT), plant height (PHT), culm length (CLT), panicle length (PLT), number of tillers plant ${ }^{-1}$ (TPP), number of effective tillers plant $^{-1}$ (ETP), non-effective tillers plant ${ }^{-1}$ (NTP), filled grains (FGP), unfilled grains (UGP), grain length (GLT), grain breadth (GBD), length-breadth ratio (LBR), straw weight (SDW), thousand grains weight (TGW) and grain yield plant $^{-1}$ (YPP).

\section{Statistical Analysis of Data}

The preface statistical analysis of the data was carried out according to standard texts and the subjects (Snedecor and Cochran, 1967; Clark, 1973). The data were subjected to the statistical software TNAUSTAR (Nadarajan et al., 2016) for the estimation of several important genetic parameters. Three types of heterosis (mid parent, better parent as well as standard heterosis) were computed by the software TNAUSTAR. In computing standard heterosis the parental genotype $\mathrm{P}_{1}$ (BRRI dhan 28) was considered as standard check as it is a mega variety of rice in Bangladesh with better yield potential.

\section{Results and Discussion}

\section{Analysis of Variance (ANOVA)}

Analysis of variance was carried out for 16 agronomic characters of five parents with their 10 hybrids (Table 1). The results revealed highly significant variability among the genotypes for most of the agronomic characters. The analysis of variances displayed vast significant differences among the genotypes (parents and hybrids) for maximum number of traits which depicts wider range of variability for the genotypes (Table 1). Similar findings were also reported by Saha et al. (2019).

The analysis of variance displayed that mean sum of squares for the genotypes were significant at $1 \%$ level $(\mathrm{P} \leq 0.01)$ for most of the agronomic traits excluding grain breadth as well 
as length breadth ratio. The higher significance differences among the genotypes for most of the traits including yield indicated that they are suitable for further genetic studies.

\section{Mean Performance of the Parents and Hybrids}

The mean values of parental genotypes and their $F_{1}$ 's are presented in the Table 2 and their corresponding analysis of variance in Table 2 . The mean values for yield along with its related traits indicated variations among the both parental as well as hybrid populations. Among the parents, $\mathrm{P}_{3}$ was found better both for early panicle exertion $(63.85$ days) and days to maturity (142.66 days) whereas $\mathrm{P}_{2}$ required longer period (78.4 days) for panicle exertion. Generally, plants with the lowest mean value for days to panicle exertion and days to maturity are desirable in rice breeding. The cross combination $\mathrm{P}_{2} \times \mathrm{P}_{3}$ showed mean value of 68.35 days for days to panicle exertion and it was intermediate to both of parents (Table 2). In case of days to maturity, $\mathrm{P}_{1} \times \mathrm{P}_{3}$ revealed the lowest mean value (139.08 days) among the $F_{1}$ 's. The parent $P_{2}$ had the shorter plant height $(92.99 \mathrm{~cm})$ than other parental genotypes which is good as shorter height is desirable trait in rice. Among the crosses, $\mathrm{P}_{2} \times \mathrm{P}_{3}$ and $\mathrm{P}_{2} \times \mathrm{P}_{4}$ produced shorter plant of 98.1 and $98.21 \mathrm{~cm}$, respectively (Table 2 ). The highest mean value for culm length was recorded in $\mathrm{P}_{5}(75.05 \mathrm{~cm})$ and shorter culm length in $\mathrm{P}_{1}(64.00 \mathrm{~cm})$. The highest culm length was produced by the crosses $\mathrm{P}_{1} \times \mathrm{P}_{5}$ and $\mathrm{P}_{2} \times \mathrm{P}_{3}(75$ and $75.05 \mathrm{~cm}$, respectively) and $\mathrm{P}_{2} \times \mathrm{P}_{4}(68.2 \mathrm{~cm})$ was found to produce shorter culm length than others (Table 2). In regard of panicle length, the hybrid $\mathrm{P}_{1} \times \mathrm{P}_{2}$ and parental genotype $\mathrm{P}_{1}$ had the highest and the lowest mean values (25.75 and $24.15 \mathrm{~cm}$, respectively) that indicated plants with the longest and the shortest culm length. Among the hybrid populations, $\mathrm{P}_{1} \times \mathrm{P}_{4}$ and $\mathrm{P}_{4} \times \mathrm{P}_{5}$ had similar culm length of $24.35 \mathrm{~cm}$ and $24.25 \mathrm{~cm}$, respectively. For tiller number plant $^{-1}$, the recombinants of $\mathrm{P}_{1} \times \mathrm{P}_{2}$ and $\mathrm{P}_{1} \times \mathrm{P}_{5}$ both had the highest mean value of 22.00 while parental genotype $\mathrm{P}_{5}$ had the lowest tiller number plant ${ }^{-1}$ which was 15.6 (Table 2).

Higher mean value for effective tillers plant ${ }^{-1}$ is one of the most important agronomic traits for selection of elite genotypes in rice breeding. The hybrids $\mathrm{P}_{1} \times \mathrm{P}_{3}, \mathrm{P}_{4} \times \mathrm{P}_{5}, \mathrm{P}_{3} \times$ $\mathrm{P}_{4}$, and $\mathrm{P}_{1} \times \mathrm{P}_{5}$ produced more number of tillers plant ${ }^{-1}$ of 19.8, 19.5, 19.3, and 19.25, respectively (Table 2). Among the parental lines, $\mathrm{P}_{1}$ and $\mathrm{P}_{3}$ possessed higher tiller number (17.0 and 17.1) compared to other three parents (Table 2). Although the highest mean value is desirable for effective tillers per plant but on the contrary, the lowest value is expected for non-effective tillers plant ${ }^{-1}$ for increasing yield. Plants with minimum non-effective tillers have been found in $\mathrm{P}_{2} \times \mathrm{P}_{4}(0.7)$. The hybrids $\mathrm{P}_{2} \times \mathrm{P}_{5}, \mathrm{P}_{3} \times \mathrm{P}_{4}$ and $\mathrm{P}_{4} \times \mathrm{P}_{5}$ had the lower value of $1.04,1.13$ and 1.17 , respectively for noneffective tiller plant ${ }^{-1}$ (Table 2). On the other hand, the hybrid $\mathrm{P}_{1} \times \mathrm{P}_{3}$ produced the highest number of non-effective tillers plant ${ }^{-1}$ and the value was 3.82 .

For filled grains panicle ${ }^{-1}$, the cross combinations $\mathrm{P}_{2} \times \mathrm{P}_{4}$ and $\mathrm{P}_{3} \times \mathrm{P}_{5}$ produced the maximum number of filled grains of 120.6 and 120.0 , respectively and that would be a good value for increasing the yield (Table 1). In case of parental genotypes, $\mathrm{P}_{3}$ produced the highest number of filled grain panicle ${ }^{-1}$ while $\mathrm{P}_{4}$ produced the lowest number of filled grains panicle ${ }^{-1}$ (Table 2). Parental genotype $\mathrm{P}_{4}$ produced minimum number of unfilled grains panicle ${ }^{-1}(21.45)$, while maximum by $\mathrm{P}_{1} \times \mathrm{P}_{2}(27.85)$.

As regards of grain length maximum mean value has been recorded for the hybrid $\mathrm{P}_{1} \times \mathrm{P}_{2}(9.1 \mathrm{~cm})$ and minimum values were found for both the hybrids $\mathrm{P}_{1} \times \mathrm{P}_{3}$ and the parent $\mathrm{P}_{5}$ (6.83). Furthermore, it has been noticed that, all parental genotypes and their hybrids had closer mean values for both the grain length and breadth (Table 2). In case of grain breath, plants of $\mathrm{P}_{1} \times \mathrm{P}_{2}$ and the parent $\mathrm{P}_{2}$ exhibited the lowest (2.29) and the highest (2.55) mean values, respectively. For grain length-breadth ratio, the mean values that have been recorded for five parents along with their respective 10 hybrids have almost similar and there were little differences among them for L-B ratio. The highest straw dry weight was recorded in hybrid $\mathrm{P}_{2} \times \mathrm{P}_{4}(35.93 \mathrm{~g})$ and the lowest $(23.58 \mathrm{~g})$ in the parental genotype $\mathrm{P}_{1}$ (Table 2 ). Maximum thousand grain weight $(33.05 \mathrm{~g})$ and yield plant ${ }^{-1}$ (43.64g) was recorded in the hybrids $\mathrm{P}_{1} \times \mathrm{P}_{4}$ and $\mathrm{P}_{3} \times \mathrm{P}_{5}$ while minimum thousand grain weight $(21.97 \mathrm{~g})$ in the hybrid $\mathrm{P}_{3} \times \mathrm{P}_{4}$ and yield plant ${ }^{-1}(24.58 \mathrm{~g})$ in the hybrid $\mathrm{P}_{1} \times \mathrm{P}_{3}$.

Lower value of coefficient of variance $(\mathrm{CV})$ is the indicator of constancy of data which can be used to validate the individual data whether it is acceptable or unacceptable. The lower value of CV for days to panicle exertion (3.59\%), days to maturity $(3.10 \%)$, plant height $(3.30 \%)$, culm length $(3.29 \%)$, filled grain $(4.15 \%)$, grain length $(1.36 \%)$, grain breadth $(2.29 \%)$, and length breadth ratio $(2.7 \%)$ suggested that the estimates were consistence and more accurate. Higher CV value implies less consistency of data as well as the estimates with less accuracy. 
Table 1. Simple analysis of variance (ANOVA) for 16 agronomic characters of $5 \times 5$ diallel populations of rice

\begin{tabular}{|c|c|c|c|c|c|c|c|c|c|c|c|c|c|c|c|c|c|}
\hline $\begin{array}{l}\text { Sources of } \\
\text { Variation }\end{array}$ & df & DPE & DMT & PHT & CLT & PLT & TPP & ETP & NTP & FGP & UGP & GLT & GBD & LBR & SDW & TGW & YPP \\
\hline Replication & 2 & 4.29 & 47.66 & 1.14 & 41.11 & 1.01 & 9.85 & 8.26 & 1.53 & 20.73 & 0.90 & 0.005 & 0.00 & 0.01 & 22.29 & 7.74 & 85.38 \\
\hline Genotypes & 28 & $44.60 * *$ & $114.70 * *$ & $25.99 * *$ & $22.44 * *$ & $0.88 \mathrm{~ns}$ & $7.31 * *$ & $3.20 * *$ & $2.63 * *$ & $63.60 * *$ & $5.99 * *$ & $1.36^{* *}$ & $0.03 \mathrm{~ns}$ & $0.28 \mathrm{~ns}$ & $23.47 * *$ & $15.55 * *$ & $75.56^{* *}$ \\
\hline Error & 29 & 12.91 & 22.10 & 11.19 & 5.03 & 0.67 & 4.24 & 3.03 & 1.11 & 21.38 & 6.40 & 0.01 & 0.005 & 0.01 & 7.69 & 7.34 & 15.56 \\
\hline
\end{tabular}

*,** represent significant at $5 \%$ and $1 \%$ level, respectively; $\mathrm{df}=$ degree of freedom; $\mathrm{ns}=$ non-significant

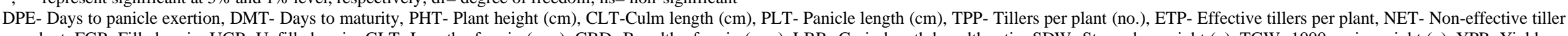

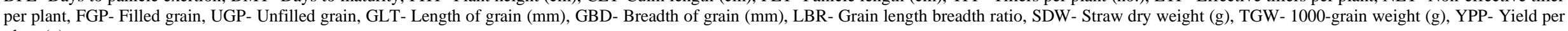
plant $(\mathrm{g})$.

Table 2. Mean values of 16 agronomic characters including grain yield per plant of $5 \times 5$ diallel populations of rice

\begin{tabular}{|c|c|c|c|c|c|c|c|c|c|c|c|c|c|c|c|c|}
\hline Genotypes & DPE & DMT & PHT & CLT & PLT & TPP & ETP & NTP & FGP & UGP & GLT & GBD & LBR & SDW & TGW & YPP \\
\hline $\mathrm{P} 1 \times \mathrm{P} 2$ & 73.81 & 152.63 & 102.65 & 73.30 & 25.35 & 22.00 & 18.05 & 3.50 & 112.20 & 27.85 & 9.10 & 2.29 & 3.97 & 31.96 & 23.48 & 28.57 \\
\hline $\mathrm{P} 1 \times \mathrm{P} 3$ & 68.95 & 139.08 & 102.20 & 72.50 & 25.60 & 21.50 & 19.80 & 3.82 & 114.85 & 25.60 & 6.83 & 2.43 & 2.81 & 27.05 & 29.70 & 24.58 \\
\hline $\mathrm{P} 1 \times \mathrm{P} 4$ & 78.64 & 159.05 & 103.85 & 69.70 & 24.35 & 21.50 & 17.45 & 3.28 & 117.50 & 24.95 & 7.01 & 2.41 & 2.91 & 28.81 & 33.05 & 37.85 \\
\hline $\mathrm{P} 1 \times \mathrm{P} 5$ & 74.82 & 153.52 & 103.20 & 75.50 & 25.75 & 22.00 & 19.25 & 3.67 & 111.45 & 26.20 & 8.58 & 2.33 & 3.68 & 30.15 & 27.86 & 26.20 \\
\hline $\mathrm{P} 2 \times \mathrm{P} 3$ & 68.35 & 140.93 & 98.10 & 75.05 & 25.10 & 21.50 & 18.70 & 3.21 & 108.05 & 22.30 & 8.96 & 2.45 & 3.65 & 27.43 & 25.42 & 39.02 \\
\hline $\mathrm{P} 2 \times \mathrm{P} 4$ & 76.46 & 153.61 & 98.21 & 68.20 & 25.20 & 17.50 & 19.08 & 0.70 & 120.60 & 23.75 & 9.06 & 2.47 & 3.68 & 35.93 & 23.94 & 26.83 \\
\hline $\mathrm{P} 2 \times \mathrm{P} 5$ & 78.90 & 159.17 & 99.00 & 73.85 & 24.80 & 18.50 & 18.94 & 1.04 & 102.10 & 25.90 & 8.64 & 2.38 & 3.62 & 28.55 & 25.48 & 37.92 \\
\hline $\mathrm{P} 3 \times \mathrm{P} 4$ & 69.11 & 156.95 & 102.30 & 73.35 & 24.40 & 19.10 & 19.30 & 1.13 & 108.05 & 23.85 & 8.21 & 2.54 & 3.23 & 31.66 & 21.97 & 41.96 \\
\hline $\mathrm{P} 3 \times \mathrm{P} 5$ & 70.00 & 141.22 & 98.25 & 71.75 & 25.20 & 18.50 & 17.95 & 0.81 & 120.60 & 22.90 & 8.56 & 2.51 & 3.41 & 30.16 & 22.42 & 43.64 \\
\hline $\mathrm{P} 4 \times \mathrm{P} 5$ & 78.23 & 157.61 & 100.55 & 73.70 & 24.25 & 19.19 & 19.50 & 1.17 & 113.10 & 23.30 & 8.21 & 2.41 & 3.41 & 30.10 & 25.06 & 40.22 \\
\hline $\mathrm{P} 1$ & 68.96 & 145.77 & 103.38 & 64.00 & 24.15 & 19.50 & 17.00 & 3.22 & 107.80 & 25.25 & 9.00 & 2.38 & 3.78 & 23.58 & 26.73 & 39.68 \\
\hline P2 & 78.40 & 161.46 & 92.99 & 66.70 & 23.45 & 19.00 & 16.55 & 3.17 & 108.60 & 23.25 & 9.01 & 2.55 & 3.53 & 25.71 & 25.87 & 32.83 \\
\hline P3 & 63.85 & 142.66 & 101.00 & 70.45 & 24.60 & 20.50 & 17.15 & 3.05 & 108.60 & 26.10 & 8.56 & 2.70 & 3.18 & 23.86 & 26.08 & 37.60 \\
\hline $\mathrm{P} 4$ & 75.99 & 152.49 & 107.96 & 73.70 & 25.55 & 17.50 & 16.15 & 2.27 & 102.10 & 21.45 & 9.05 & 2.78 & 3.26 & 25.49 & 26.34 & 30.72 \\
\hline P5 & 71.47 & 156.76 & 105.15 & 75.00 & 25.50 & 15.60 & 16.10 & 2.67 & 111.80 & 23.65 & 6.83 & 2.53 & 2.70 & 24.83 & 25.58 & 35.66 \\
\hline Max. & 78.90 & 161.46 & 107.96 & 75.05 & 25.75 & 22.00 & 19.80 & 3.82 & 117.50 & 27.85 & 9.10 & 2.78 & 3.97 & 35.93 & 33.05 & 43.64 \\
\hline Min. & 63.85 & 139.08 & 92.99 & 64.00 & 24.15 & 15.60 & 16.10 & 0.70 & 102.60 & 22.23 & 6.83 & 2.29 & 2.70 & 23.58 & 21.97 & 24.58 \\
\hline $\mathrm{CV}(\%)$ & 3.59 & 3.10 & 3.30 & 3.12 & 3.29 & 10.52 & 9.64 & 43.06 & 4.15 & 10.35 & 1.36 & 2.77 & 2.93 & 9.78 & 10.44 & 11.30 \\
\hline LSD & 2.54 & 4.70 & 3.34 & 2.24 & 2.44 & 2.05 & 1.74 & 1.05 & 4.62 & 2.52 & 0.11 & 0.06 & 0.09 & 2.77 & 2.70 & 3.94 \\
\hline
\end{tabular}

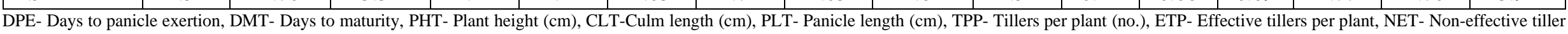

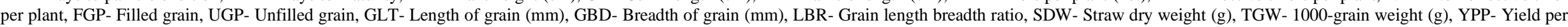
plant $(\mathrm{g})$. 


\section{Evaluation of Heterosis}

Heterosis has been computed as regards of percent increase or decrease of values in the first filial generation $\left(\mathrm{F}_{1}\right)$ over mid parent, better parent (heterobeltiosis) and standard check. The results are presented in Table 3, 4 and 5.

\section{Mid Parent Heterosis (Relative Heterosis):}

The estimates of heterosis over mid parent for 10 cross combinations in 16 agronomic traits are presented in Table 3 . In the present study, none of the cross combination revealed significant desirable heterosis over mid parent for all characters. Generally, negative heterosis is desirable for days to flowering, days to maturity as they will produce flower earlier and also will mature earlier as compared to parents. Similarly, for plant height, breeder prefers shorter and dwarf statured plant in rice breeding, thus negative significant values are preferable for heterosis.

The hybrid $\mathrm{P}_{2} \times \mathrm{P}_{3}$ exhibited highly significant negative heterosis value over mid parent for days to panicle exertion and days to maturity. The cross combinations $\mathrm{P}_{2} \times \mathrm{P}_{4}$ and $\mathrm{P}_{3} \times \mathrm{P}_{5}$ showed significant negative heterosis for both the trait of days to maturity and plant height. Kumar et al. (2020) also found similar results in case of days to flowering and days to maturity. For plant height, highly significant negative heterosis was recorded in the cross combinations of $\mathrm{P}_{4} \times \mathrm{P}_{5}$ and $\mathrm{P}_{3} \times \mathrm{P}_{5}$ (Table 3). The hybrids $\mathrm{P}_{1} \times \mathrm{P}_{2}, \mathrm{P}_{1} \times \mathrm{P}_{3}$, $\mathrm{P}_{2} \times \mathrm{P}_{3}$ and $\mathrm{P}_{2} \times \mathrm{P}_{4}$ had highly significant positive heterosis over mid parents for panicle length, effective tillers plant ${ }^{-1}$ and filled grains panicle ${ }^{-1}$ and grain yield plant ${ }^{-1}$ except $\mathrm{P}_{1} \times \mathrm{P}_{2}$, which has negative heterosis for grain yield plant ${ }^{-1}$. In case of effective tillers plant ${ }^{-1}$ and straw dry weight, all cross combinations had highly significant and positive heterosis over mid parent and none of the hybrids showed negative values for these traits. The hybrids of $\mathrm{P}_{3} \times \mathrm{P}_{5}$ would produce rice with longer grain with shorter breadth as this hybrid produced the highest significant and positive heterosis for grain length but negative heterosis for grain breadth. The maximum mid parent heterosis was found in $\mathrm{P}_{1} \times \mathrm{P}_{4}$ for thousand grain weight. As yield is the ultimate goal of rice breeding, highly significant positive heterosis estimates are desirable for increasing grain yield plant ${ }^{-1}$ and the hybrid $\mathrm{P}_{2} \times \mathrm{P}_{4}$ had the highest heterosis value (Table 3).

It was noticed that none of the cross combination showed desirable heterosis over mid parent regarding all the traits. More than $65 \%$ hybrid combinations showed significant positive and desirable heterosis for grain yield plant ${ }^{-1}$, indicating that it would be effective to choose these hybrids for these traits to increase the yield. It was also observed that, parents of all the hybrids performed both as good and poor combiners in different aspect, indicating the presence of dominance gene action. Thus, these hybrids can be recommended for heterosis breeding.
Better Parent Heterosis (Heterobeltiosis):

The estimates of heterosis over better parent for 10 cross combinations in 16 agronomic traits are presented in Table 4.

The cross combinations $\mathrm{P}_{1} \times \mathrm{P}_{2}, \mathrm{P}_{2} \times \mathrm{P}_{3}$ and $\mathrm{P}_{3} \times \mathrm{P}_{5}$ exhibited significant negative heterosis over better parent for days to panicle exertion and days to maturity. While, the hybrids of $\mathrm{P}_{1} \times \mathrm{P}_{3}$ and $\mathrm{P}_{2} \times \mathrm{P}_{3}$ had significant negative heterosis over better parent for plant height indicating shorter plant height and significant positive heterosis for panicle length (Table 4).

Regarding the number of tiller plant ${ }^{-1}$ and effective tillers, cross combinations of $\mathrm{P}_{1} \times \mathrm{P}_{2}, \mathrm{P}_{1} \times \mathrm{P}_{3}, \mathrm{P}_{1} \times \mathrm{P}_{4}, \mathrm{P}_{1} \times \mathrm{P}_{5}, \mathrm{P}_{2} \times \mathrm{P}_{3}$ and $\mathrm{P}_{4} \times \mathrm{P}_{5}$ gave significant positive heterosis over the better parent and could be utilized in the exploitation of heterosis for these traits. Moreover, the estimates for effective tillers plant $^{-1}$ revealed that all the hybrid combinations exhibited significant positive heterosis over the better parent.

Highly significant positive heterobeltiosis was observed in the crosses $\mathrm{P}_{1} \times \mathrm{P}_{4}, \mathrm{P}_{3} \times \mathrm{P}_{5}$ and $\mathrm{P}_{1} \times \mathrm{P}_{3}$ for filled grains panicle ${ }^{1}$ (Table 4). On the other hand, the crosses $\mathrm{P}_{1} \times \mathrm{P}_{2}, \mathrm{P}_{2} \times \mathrm{P}_{5}$ and $\mathrm{P}_{1} \times \mathrm{P}_{5}$ had highly significant positive value for unfilled grains panicle ${ }^{-1}$ implying more number of empty grains in the hybrid population. More filled grains panicle ${ }^{-1}$ is desirable in rice breeding for increasing the grain yield plant $^{-1}$. Now days, longer but fine-grained rice is more preferable, thus positive heterosis would be a good indicator for grain length and negative heterosis for grain breadth. But it was observed that, most of the cross combinations produced significant negative heterosis estimates for grain length and breadth over better parent.

Considering thousand grain weight, cross combinations $\mathrm{P}_{1} \times \mathrm{P}_{4}$ and $\mathrm{P}_{1} \times \mathrm{P}_{3}$ had highly significant positive heterosis over better parent (Table 4). These crosses would not be efficient for utilization in breeding program where yield is the major concern as they have not exhibited positive heterosis for grain yield plant $^{-1}$. They showed highly significant negative heterosis over better parent for grain yield plant ${ }^{-1}$. In case of straw dry weight, none of the crosses had negative heterosis over better parent.

Among the 10 cross combinations, $\mathrm{P}_{3} \times \mathrm{P}_{5}, \mathrm{P}_{4} \times \mathrm{P}_{5}$ and $\mathrm{P}_{3} \times \mathrm{P}_{4}$ had highly significant positive heterosis for grain yield plant $^{-1}$ over better parent. Five hybrids manifested significant positive heterosis for grain yield over better parent, would perform better in the hybrid breeding program for increasing grain yield. The magnitude of heterosis over better parent greatly varied from trait to trait as well as parent to parent. Similar findings were reported by Abo-Yousef et al. (2020). 
Table 3: Estimation of heterosis of $F_{1}$ hybrids over mid parent (relative heterosis) for 16 agronomic characters in boro rice

\begin{tabular}{|c|c|c|c|c|c|c|c|c|c|c|c|c|c|c|c|c|}
\hline Genotypes & DPE & DMT & PHT & CLT & PLT & TPP & ETP & NTP & FGP & UGP & GLT & GBD & LBR & SDW & TGW & YPP \\
\hline $\mathrm{P} 1 \times \mathrm{P} 2$ & $0.18 \mathrm{~ns}$ & $-0.64 \mathrm{~ns}$ & $4.55^{* *}$ & $12.17 * *$ & $6.51 * *$ & $14.29 * *$ & $7.6^{* * *}$ & $9.64 * *$ & $3.7 * *$ & $14.85^{* *}$ & $1 * *$ & $-7.29 * *$ & $8.76^{* *}$ & $29.68 * *$ & $-10.73 * *$ & $-21.22 * *$ \\
\hline $\mathrm{P} 1 \times \mathrm{P} 3$ & $3.83 * *$ & $-3.56 * *$ & $0.01 \mathrm{~ns}$ & $7.85^{* *}$ & $5.03 * *$ & $7.5^{* *}$ & $15.96 * *$ & $21.7 * *$ & $6.15^{* *}$ & $-0.29 \mathrm{~ns}$ & $-22.24 * *$ & $-4.13 * *$ & $-19.18 * *$ & $14.04 * *$ & $12.48 * *$ & $-36.38 * *$ \\
\hline $\mathrm{P} 1 \times \mathrm{P} 4$ & $8.5 * *$ & $6.65 * *$ & $-1.72 *$ & $1.23 *$ & $-2.01 * *$ & $16.22 * *$ & $5.28 * *$ & $19.23 * *$ & $11.96^{* *}$ & $6.85^{* *}$ & $-22.33 * *$ & $-6.87 * *$ & $-17.17 * *$ & $17.42 * *$ & $24.56^{* *}$ & $7.53 * *$ \\
\hline $\mathrm{P} 1 \times \mathrm{P} 5$ & $6.55^{* *}$ & $1.49 *$ & $-1.02 *$ & $8.63 * *$ & $3.73 * *$ & $25.36 * * * *$ & $16.31 * *$ & $24.84 * *$ & $1.5^{*}$ & $7.16^{* *}$ & $8.43 * *$ & $-5.19 * *$ & $13.76^{* *}$ & $24.56^{* *}$ & $6.53 * *$ & $-30.45 * *$ \\
\hline $\mathrm{P} 2 \times \mathrm{P} 3$ & $-3.9 * *$ & $-7.32 * *$ & $1.14 *$ & $9.44 * *$ & $4.47 * *$ & $8.86 * *$ & $10.98^{* *}$ & $3.16^{* *}$ & $-0.51 \mathrm{~ns}$ & $-9.63 * *$ & $2.03 * *$ & $-6.48 * *$ & $8.96 * *$ & $10.67 * *$ & $-2.14^{*}$ & $10.79 * *$ \\
\hline $\mathrm{P} 2 \times \mathrm{P} 4$ & $-0.96 \mathrm{~ns}$ & $-2.14 * *$ & $-2.36^{* *}$ & $-2.85^{* *}$ & $2.86^{* *}$ & $-4.11 * *$ & $16.67 * *$ & $-74.3 * *$ & $14.48 * *$ & $6.26 * *$ & $0.33 \mathrm{~ns}$ & $-7.59 * *$ & $8.34 * *$ & $40.35 * *$ & $-8.29 * *$ & $-15.55 * *$ \\
\hline $\mathrm{P} 2 \times \mathrm{P} 5$ & $5.29 * *$ & $0.04 \mathrm{~ns}$ & $-0.07 \mathrm{~ns}$ & $4.23 * *$ & $1.33 *$ & $6.94 * *$ & $16.05^{* * *}$ & $-64.37 * *$ & $-7.35^{* *}$ & $10.45^{* *}$ & $9.03 * *$ & $-6.19 * *$ & $16.31 * *$ & $12.98 * *$ & $-0.94 n s$ & $10.72 * *$ \\
\hline $\mathrm{P} 3 \times \mathrm{P} 4$ & $-1.16^{*}$ & $6.35^{* *}$ & $-2.09 * *$ & $1.77 *$ & $-2.69 * *$ & $0.53 \mathrm{~ns}$ & $15.92 * *$ & $-57.56 * *$ & $2.56^{*}$ & $0.32 \mathrm{~ns}$ & $-6.78 * *$ & $-7.21 * *$ & $0.41 \mathrm{~ns}$ & $28.31 * *$ & $-16.19 * *$ & $22.81 * *$ \\
\hline $\mathrm{P} 3 \times \mathrm{P} 5$ & $3.45^{* *}$ & $-5.67 * *$ & $-4.68 * *$ & $-1.34 *$ & $0.6 \mathrm{~ns}$ & $2.49 * *$ & $7.97 * *$ & $-71.67 * *$ & $9.44 * *$ & $-7.94 * *$ & $11.27 * *$ & $-3.92 * *$ & $16.16^{* *}$ & $23.89 * *$ & $-13.2^{* *}$ & $19.13 * *$ \\
\hline $\mathrm{P} 4 \times \mathrm{P} 5$ & $6.09 * *$ & $1.93 *$ & $-5.63 * *$ & $-0.87 n s$ & $-5 * *$ & $15.98 * *$ & $20.93 * *$ & $-52.43 * *$ & $5.75^{* *}$ & $3.33 * *$ & $3.39 * *$ & $-9.23 * *$ & $14.3^{* * *}$ & $19.63 * *$ & $-3.48 * *$ & $21.17 * *$ \\
\hline
\end{tabular}

*,** represent significant at $5 \%$ and $1 \%$ level, respectively; $\mathrm{df}=$ degree of freedom; ns= non-significant

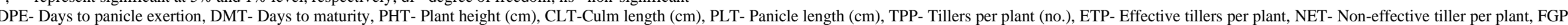
Filled grain, UGP- Unfilled grain, GLT- Length of grain (mm), GBD- Breadth of grain (mm), LBR- Grain length breadth ratio, SDW- Straw dry weight (g), TGW- 1000-grain weight (g), YPP- Yield per plant (g).

Table 4: Estimation of heterosis of $\mathrm{F}_{1}$ hybrids over better parent (Heterobeltiosis) for 16 agronomic characters in boro rice

\begin{tabular}{|c|c|c|c|c|c|c|c|c|c|c|c|c|c|c|c|c|}
\hline Genotypes & DPE & DMT & $\begin{array}{l}\text { PHT } \\
\end{array}$ & CLT & PLT & TPP & ETP & NTP & FGP & UGP & GLT & GBD & LBR & SDW & TGW & YPP \\
\hline $\mathrm{P} 1 \times \mathrm{P} 2$ & $-5.85 * *$ & $-5.47 * *$ & $-0.71 \mathrm{~ns}$ & $9.9^{* *}$ & $4.97 * *$ & $12.82 * *$ & $6.18^{* *}$ & $8.81 * *$ & $3.31 *$ & $10.3^{* *}$ & $0.92 \mathrm{~ns}$ & $-10.37 * 8$ & $5.2 * *$ & $24.31 * *$ & $-12.17 * *$ & $-28.01 * *$ \\
\hline $\mathrm{P} 1 \times \mathrm{P} 3$ & $-0.01 n s$ & $-4.59 * *$ & $-1.14^{*}$ & $2.91^{*}$ & $4.07 * *$ & $4.88^{* *}$ & $15.45^{* *}$ & $18.51^{* *}$ & $5.76 * *$ & $-1.92 * *$ & $-24.13^{* *}$ & $-9.65 * *$ & $-25.6^{* *}$ & $13.37 * *$ & $11.12 * *$ & $-38.04 * *$ \\
\hline $\mathrm{P} 1 \times \mathrm{P} 4$ & $3.48 * *$ & $4.3 * *$ & $-3.8 * *$ & $-5.43 * *$ & $-4.7 * *$ & $10.26^{* * *}$ & $2.65^{*}$ & $1.72 *$ & $9 * *$ & $-1.19 *$ & $-22.57 * 8$ & $-13.49 * *$ & $-22.8^{* *}$ & $13.02 * *$ & $23.65 * *$ & $-4.61 *$ \\
\hline $\mathrm{P} 1 \times \mathrm{P} 5$ & $4.68 * *$ & $-2.06^{*}$ & $-1.85^{*}$ & $0.67 \mathrm{~ns}$ & $0.98 \mathrm{~ns}$ & $12.82 * *$ & $13.24 * *$ & $14.12 * *$ & $-0.31 \mathrm{~ns}$ & $3.76^{* * *}$ & $-4.66^{* *}$ & $-7.91 * *$ & $-2.48 * *$ & $21.43 * *$ & $4.23^{*}$ & $-33.97 * *$ \\
\hline $\mathrm{P} 2 \times \mathrm{P} 3$ & $-12.81 * *$ & $-12.71 * *$ & $-2.87 *$ & $6.53 * *$ & $2.03^{*}$ & $4.88 * *$ & $9.04 * *$ & $1.21^{*}$ & $-0.51 \mathrm{~ns}$ & $-14.56^{* *}$ & $-0.54 n s$ & $-8.91 * *$ & $3.51 * *$ & $6.69 * *$ & $-2.55 n s$ & $3.76^{*}$ \\
\hline $\mathrm{P} 2 \times \mathrm{P} 4$ & $-2.48 *$ & $-4.86^{* *}$ & $-9.13 * *$ & $-7.46 * *$ & $-1.37 *$ & $-7.89 * *$ & $15.26 * *$ & $-77.94 * *$ & $11.05 * *$ & $2.15^{* *}$ & $0.1 \mathrm{~ns}$ & $-11.33 * *$ & $4.24 * *$ & $39.75 * *$ & $-9.11 * *$ & $-18.27 * *$ \\
\hline $\mathrm{P} 2 \times \mathrm{P} 5$ & $0.64 \mathrm{~ns}$ & $-1.42^{*}$ & $-5.85 * *$ & $-1.53^{*}$ & $-2.75^{*}$ & $-2.63 *$ & $14.47 * *$ & $-67.2^{* *}$ & $-8.68 * *$ & $9.51^{* *}$ & $-4.19 * *$ & $-6.65 * *$ & $2.62 * *$ & $11.05 * *$ & $-1.5 \mathrm{~ns}$ & $6.34 *$ \\
\hline $\mathrm{P} 3 \times \mathrm{P} 4$ & $-9.06^{* *}$ & $2.92 *$ & $-5.24 * *$ & $-0.47 \mathrm{~ns}$ & $-4.5 * *$ & $-6.83 *$ & $12.54 * *$ & $-62.96 * *$ & $-0.51 \mathrm{~ns}$ & $-8.62 * *$ & $-9.32 * *$ & $-8.63 * *$ & $-0.9 \mathrm{~ns}$ & $24.21 * *$ & $-16.6^{* *}$ & $11.57 * *$ \\
\hline $\mathrm{P} 3 \times \mathrm{P} 5$ & $-2.06^{*}$ & $-9.91 * *$ & $-6.56 * *$ & $-4.33 * *$ & $-1.18 *$ & $-9.76^{*}$ & $4.66^{* * *}$ & $-73.45^{* *}$ & $7.87 * *$ & $-12.26^{* *}$ & $0.01 \mathrm{~ns}$ & $-6.86 * *$ & $7.41 * *$ & $21.47 * *$ & $-14.04 * *$ & $16.05 * *$ \\
\hline $\mathrm{P} 4 \times \mathrm{P} 5$ & $2.93 *$ & $0.55 \mathrm{~ns}$ & $-6.86 * *$ & $-1.73^{*}$ & $-5.09 * *$ & $9.69 * *$ & $20.74 * *$ & $-55.93 * *$ & $1.16^{*}$ & $-1.48 *$ & $-9.32 * *$ & $-13.31 * *$ & $4.43 * *$ & $18.09 * *$ & $-4.88 *$ & $12.77 * *$ \\
\hline
\end{tabular}

*,** represent significant at $5 \%$ and $1 \%$ level, respectively; $\mathrm{df}=$ degree of freedom; ns= non-significant

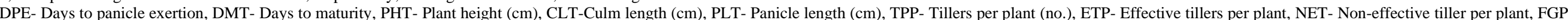
Filled grain, UGP- Unfilled grain, GLT- Length of grain (mm), GBD- Breadth of grain (mm), LBR- Grain length breadth ratio, SDW- Straw dry weight (g), TGW- 1000-grain weight (g), YPP- Yield per plant (g). 
Table 5: Estimation of heterosis of $F_{1}$ hybrids over standard parent (Economic/Standard Heterosis) for 16 agronomic characters in boro rice

\begin{tabular}{|c|c|c|c|c|c|c|c|c|c|c|c|c|c|c|c|c|}
\hline Genotypes & DPE & DMT & PHT & CLT & PLT & TPP & ETP & NTP & FGP & UGP & GLT & GBD & LBR & SDW & TGW & YPP \\
\hline $\mathrm{P} 1 \times \mathrm{P} 2$ & $7.03 * *$ & $4.7 *$ & $-0.71 \mathrm{~ns}$ & $14.53 * *$ & $4.97 * *$ & $12.82 * *$ & $6.18 * *$ & $8.81 * *$ & $4.08 * *$ & $10.3^{* *}$ & $1.09 *$ & $-3.98 * *$ & $5.2 * *$ & $35.54 * *$ & $-12.17 * *$ & $-28.01 * *$ \\
\hline $\mathrm{P} 1 \times \mathrm{P} 3$ & $-0.01 \mathrm{~ns}$ & $-4.59 *$ & $-1.14 *$ & $13.28 * *$ & $6^{* *}$ & $10.26 * *$ & $16.47 * *$ & $18.51 * *$ & $6.54 * *$ & $1.39 *$ & $-24.13 * *$ & $2.1 * *$ & $-25.6^{* *}$ & $14.72 * *$ & $11.12 * *$ & $-38.04 * *$ \\
\hline $\mathrm{P} 1 \times \mathrm{P} 4$ & $14.03 * *$ & $9.11 * *$ & $0.45 \mathrm{~ns}$ & $8.91 * *$ & $0.83 \mathrm{~ns}$ & $10.26 * *$ & $2.65 \mathrm{~ns}$ & $1.72 *$ & $9 * *$ & $-1.19^{*}$ & $-22.09 * *$ & $0.84 \mathrm{~ns}$ & $-22.8^{* *}$ & $22.18 * *$ & $23.65 * *$ & $-4.61 \mathrm{~ns}$ \\
\hline $\mathrm{P} 1 \times \mathrm{P} 5$ & $8.49 * *$ & $5.31 * *$ & $-0.17 \mathrm{~ns}$ & $17.97 * *$ & $6.63^{* *}$ & $12.82^{* *}$ & $13.24 * *$ & $14.12^{* *}$ & $3.39 * *$ & $3.76^{* *}$ & $-4.66 * *$ & $-2.31 * *$ & $-2.48^{* *}$ & $27.86^{* *}$ & $4.23 * *$ & $-33.97 * *$ \\
\hline $\mathrm{P} 2 \times \mathrm{P} 3$ & $-0.88 \mathrm{~ns}$ & $-3.32 *$ & $-5.11 * *$ & $17.27 * *$ & $3.93 * *$ & $10.26 * *$ & 10 ** & $-0.33 n s$ & $0.23 \mathrm{~ns}$ & $-11.68 * *$ & $-0.37 \mathrm{~ns}$ & $2.94 * *$ & $-3.26 * *$ & $16.33 * *$ & $-4.91 * *$ & $-1.66 \mathrm{~ns}$ \\
\hline $\mathrm{P} 2 \times \mathrm{P} 4$ & $10.87 * *$ & $5.38 * *$ & $-5.11 * *$ & $6.56 * *$ & $4.35 * *$ & $-10.43 * *$ & $12.21 * *$ & $-78.27 * *$ & $11.87 * *$ & $-5.94 * *$ & $0.72 \mathrm{~ns}$ & $3.35^{* *}$ & $-2.58^{* *}$ & $52.37 * *$ & $-10.44 * *$ & $-32.37 * *$ \\
\hline $\mathrm{P} 2 \times \mathrm{P} 5$ & $14.41 * 8$ & $9.19 * *$ & $-4.24 * *$ & $15.39 * *$ & $2.69 *$ & $-5.13 * *$ & $11.44 * *$ & $-67.7 * *$ & $-5.29 * *$ & $2.57 * *$ & $-4.03 * *$ & $0.12 \mathrm{~ns}$ & $-4.09 * *$ & $21.08 * *$ & $-4.68 * *$ & $-4.44 \mathrm{~ns}$ \\
\hline $\mathrm{P} 3 \times \mathrm{P} 4$ & $0.22 \mathrm{~ns}$ & $7.66 * *$ & $-1.04^{*}$ & $14.61 * *$ & $1.04 *$ & $-2.05^{*}$ & $13.53 * *$ & $-64.9 * *$ & $0.23 \mathrm{~ns}$ & $-5.54 * *$ & $-8.76 * *$ & $6.5^{* *}$ & $-14.4^{* *}$ & $34.27 * *$ & $-17.82 * 8$ & $5.73 *$ \\
\hline $\mathrm{P} 3 \times \mathrm{P} 5$ & $1.51^{*}$ & $-3.12 *$ & $-4.96 * *$ & $12.11 * *$ & $4.35 * *$ & $-5.13 *$ & $5.59 * *$ & $-74.84 * *$ & $11.87 * *$ & $-9.31 * *$ & $-4.87 * *$ & $5.24 * *$ & $-9.64 * *$ & $27.91 * *$ & $-16.13 * *$ & $9.98 * *$ \\
\hline $\mathrm{P} 4 \times \mathrm{P} 5$ & $13.44 * *$ & $8.12 * *$ & $-2.74 *$ & $15.16^{* *}$ & $0.41 \mathrm{~ns}$ & $1.56 \mathrm{~ns}$ & $14.71 * *$ & $-63.5^{* *}$ & $4.92 * *$ & $-7.72 * *$ & $-8.76^{* *}$ & $1.05^{*}$ & $-9.79 * *$ & $27.65 * *$ & $-6.27 * *$ & $1.35 \mathrm{~ns}$ \\
\hline
\end{tabular}

*,** represent significant at $5 \%$ and $1 \%$ level, respectively; $\mathrm{df}=$ degree of freedom; $\mathrm{ns}=$ non-significant

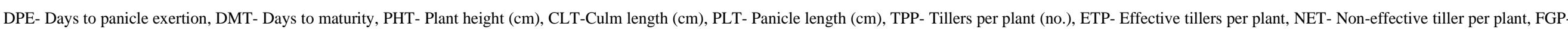
Filled grain, UGP- Unfilled grain, GLT- Length of grain (mm), GBD- Breadth of grain (mm), LBR- Grain length breadth ratio, SDW- Straw dry weight (g), TGW- 1000-grain weight (g), YPP- Yield per plant (g). 
Heterosis over Standard Parent (Economic Heterosis):

Data on estimates of heterosis over standard parent implies superiority or inferiority in the performance of hybrids in comparison to standard parent concerning specific trait. The estimates of heterosis over standard parent has been presented in Table 5. A wide range of variation was observed in the estimates of standard heterosis both in positive and negative direction for grain yield plant ${ }^{-1}$. None of the hybrid showed significant negative heterosis over standard parent for days to panicle exertion, rather most of the cross combinations exhibited highly significant positive heterosis for days to panicle exertion implies late flowering in the hybrid combinations. The hybrids combinations $\mathrm{P}_{1} \times \mathrm{P}_{2}$ and $\mathrm{P}_{2} \times \mathrm{P}_{3}$ together with $\mathrm{P}_{3} \times \mathrm{P}_{5}$ revealed early maturity and shorter statured plant the standard heterosis value was significant and negative for days to maturity and plant height. It was notified that, none of the hybrids had negative heterosis for both culm length and panicle length over standard parent, rather most of the cross combinations possessed highly significant positive heterosis except $\mathrm{P}_{1} \times \mathrm{P}_{4}$ and $\mathrm{P}_{4} \times \mathrm{P}_{5}$ which showed non-significant and positive heterosis for panicle length. Highly significant positive heterosis was recorded in the hybrid combinations $\mathrm{P}_{1} \times \mathrm{P}_{2}$, $\mathrm{P}_{1} \times \mathrm{P}_{3}, \mathrm{P}_{1} \times \mathrm{P}_{4}, \mathrm{P}_{1} \times \mathrm{P}_{5}$ and $\mathrm{P}_{2} \times \mathrm{P}_{3}$ for tillers plant ${ }^{-1}$ and most of hybrid combinations exhibited significant positive estimates for effective tillers plant ${ }^{-1}$ over the standard parent. Significant negative heterosis are desirable in regards to non-effective tillers plant ${ }^{-1}$.

Six hybrid combinations were found to have negative heterosis for non-effective tillers plant ${ }^{-1}$, among which the hybrid $\mathrm{P}_{2} \times \mathrm{P}_{5}$ have the highest estimates over standard parent for non-effective tillers plant $^{-1}$. Maximum and significant positive heterosis was found in the hybrid combinations $\mathrm{P}_{2} \times \mathrm{P}_{4}$ and $\mathrm{P}_{3} \times \mathrm{P}_{5}$ for filled grains panicle ${ }^{-1}$ while $\mathrm{P}_{2} \times \mathrm{P}_{3}$ had significant negative heterosis for unfilled grains panicle ${ }^{-1}$ over standard parent. All cross combinations had significant positive heterosis for straw dry weight among which $\mathrm{P}_{2} \times \mathrm{P}_{4}$ had the maximum standard heterosis.

Majority of cross combinations performed better for shorter and finer grain as produced highly significant negative standard (economic) heterosis for both grain length and length breadth ration over the standard parent except $\mathrm{P}_{1} \times \mathrm{P}_{2}$. It was found that, most of the hybrids did not have desirable significant positive heterosis for thousand grain weight and grain yield plant ${ }^{-1}$ except fewer hybrids. Only two hybrid combinations $\mathrm{P}_{3} \times \mathrm{P}_{5}$ and $\mathrm{P}_{3} \times \mathrm{P}_{4}$ showed significant positive economic heterosis for grain yield over standard parent which is desirable.

\section{Conclusion}

The analysis of variance (ANOVA) exhibited highly significant variations among the genotypes for all the characters except grain breadth and length breadth ratio. The hybrid combination $\mathrm{P}_{3} \times \mathrm{P}_{5}$ exhibited as the best performer for filled grain and grain yield plant ${ }^{-1}$. While the parental genotype $\mathrm{P}_{3}$ exhibited desired mean value for panicle exertion and days to maturity. The parental combination $\mathrm{P}_{2} \times \mathrm{P}_{3}$ exhibited desirable positive heterosis over the both mid and better parent for days to maturity followed by days to flowering, panicle length, number of effective tillers panicle ${ }^{-1}$, grain length and grain yield plant ${ }^{1}$. On the other hand, cross combination $\mathrm{P}_{1} \times \mathrm{P}_{4}$ revealed as good performer for plant height, number of effective tillers plant $^{-1}$ and filled grains panicle ${ }^{-1}$, thousand grain weight and grain yield over mid parent. In regards to standard heterosis, the cross combination $\mathrm{P}_{3} \times \mathrm{P}_{5}$ would be a good combination for early flowering with early maturity, shorter plant stature, higher number of effective tillers plant $^{-1}$, filled grains panicle $^{-1}$ and maximum grain yield plant ${ }^{-1}$ revealed its candidature for selecting as superior genotypes over standard variety.

\section{Authors' Contribution}

A.K.M. Aminul Islam designed the research plan; Shuma Rani Ray performed experimental works \& collected the required data. Shuma Rani Ray \& A.K.M. Aminul Islam analysed the data; Shuma Rani Ray prepared the manuscript. A.K.M. Aminul Islam, M.G. Rasul, M.M. Hasan Saikat \& J.U. Ahmed critically revised and finalized the manuscript. Final form of manuscript was approved by all authors.

\section{Conflict of Interest}

The authors declare that there is no conflict of interest with present publication.

\section{Acknowledgements}

The authors would like to acknowledge their gratitude towards Ministry of Education, Bangladesh and Bangabandhu Sheikh Mujibur Rahman Agricultural University, Gazipur 1706, Bangladesh authority for their support through the project entitled "Genetic Analysis for Salt Tolerance in Rice (Oryza sativa L.)", Grant No. LS2018732.

\section{References}

Abo-Yousef MI, Ghidan WF, Talha IA, Elsehely AB and Tabl DM (2020) Combining ability, heterosis and gene action for grain yield and its related traits of some WA-CMS with tester lines of rice (Oryza sativa L.). Journal of Experimental Agriculture International 42(9): 102-123. DOI: $\underline{10.9734 / j e a i / 2020 / v 42 i 930592}$

BRRI (2018) Modern Rice Cultivation, Twenty edition. Gazipur, Bangladesh. 91p.

Clark GM (1973) Statistics and experimental design. Edward Arnold, London.

Ghidan WF, El-Agoury RY and Hussein FA (2019) Utilization of combining ability and genetic components for yield and its contributing traits of some rice (Oryza sativa L.) Genotypes. Journal of Agricultural Chemistry and 
Biotechnology 10(12): 257-267. DOI: $\underline{10.21608 / j a c b .2019 .71149}$

Gupta SK (2000) Plant breeding: Theory and techniques. Published by Updesh Purohit for Agrobios. India. Indian Journal of Agricultural Science 71: 344-345.

Gupta SK, Patil KS, Rathore A, Yadav DV, Sharma LD, Mungra KD, Patil HT, Gupta SK, Kumar R, Chaudhary V, Das RR, Kumar A, Singh V, Srivastava RK, Gupta R, Boratkar M, Varshney RK, Rai KN and Yadav OP (2020). Identification of heterotic groups in South-Asian-bred hybrid parents of pearl millet. Theoretical and Applied Genetics 133(3): 873-888. DOI: 10.1007/s00122-019$\underline{03512-\mathrm{z}}$

Ismaeel M, Shah SMA, Suliman S, Raza A, Anwar M (2019) Assessment of genetic variability, heterosis and heritability for morphological parameters in rice. Pure and Applied Biology (PAB), 8(1): 160-168.

Jones JW (1926) Hybrid vigor in rice. Agronomy Journal 18(5): 423-428.

DOI: 10.2134/agronj1926.00021962001800050010x

Kumar CPS, Sathiyabama R, Suji DB and Muraleedharan A (2020) Estimation of heterosis for earliness and certain growth characters in rice (Oryza sativa L.). Plant Archives 20(2): 1429-1432.

Kumar V, Mishra DP, Yadav GC, Yadav S (2018) Exploitation of heterobeltiosis and economic heterosis for horticultural yield, and its attributes and biochemical traits in pumpkin (Cucurbita moschata Duch. ex. Poir) under salt affected soil. Current Science 115(8): 1550-1556. DOI: 10.18520/cs/v115/i8/1550-1556

Lv Q, Li W, Sun, Z, Ouyang N, Jing X, He Q, Wu J, Zheng J, Zheng J, Tang S, Zhu R, Tian Y, Duan M, Tan Y, Yu D,
Sheng X, Sun X, Jia G, Gao H, Zeng Q, Li Y, Tang L, Xu Q, Zhao B, Huang Z, Lu H, Li N, Zhao J, Zhu L, Li D, Yuan L, Yuan D (2020) Resequencing of 1,143 indica rice accessions reveals important genetic variations and different heterosis patterns. Nature Communications 11(1): 1-10. DOI: $\underline{10.1038 / \mathrm{s} 41467-020-}$ $\underline{18608-0}$

Nadarajan N, Manivannan N, Gunasekaran M (2016) Quantitative genetics and biometrical techniques in plant breeding, Kalyani Publishers, Ludhiana, India, 324p.

Rahimi M, Rabiei B, Samizadeh H, Kafi GA (2010) Combining ability and heterosis in rice (Oryza sativa L.) cultivars. JAST 12(2): 223-231.

Saha SR, Hassan L, Haque MA, Islam MM, Rasel M (2019) Genetic variability, heritability, correlation and path analyses of yield components in traditional rice (Oryza sativa L.) landraces. Journal of the Bangladesh Agricultural University 17(1): 26-32. DOI: $\underline{10.3329 / j b a u . v 17 i 1.40659}$

Shull GH (1914). Duplicate genes for capsule form in Bursa bursa pastoris. Zeitschr indukt Abstammungs- und Vererbungslehre 12: 97-149. DOI: 10.1007/BF01837282

Singh NK, Singh AK, Singh AK, Misra V, Mall AK (2019) Heterosis breeding in rice (Oryza sativa L.) for quantitative traits. Plant Archives 19(1): 544-548.

Snedecor GW and Cochran WG (1967) Statistical methods. Ames, IA: Iowa State University.

Sundaram KM, Rajeswari S, Saraswathi R and Jeyaprakash P (2019) Heterosis and combining ability analysis for yield related traits in rice hybrids involving land races. Electronic Journal of Plant Breeding 10(1): 92-100. DOI: $\underline{10.5958 / 0975-928 X .2019 .00011 .5}$ 